\title{
Depression in Resident Physicians: A Systematic Review
}

\author{
Nasheel Joules ${ }^{1}$, Daniel M. Williams' ${ }^{2}$ Alexander W. Thompson ${ }^{2}$ \\ ${ }^{1}$ Texoma Medical Center, Denison, TX, USA \\ ${ }^{2}$ Department of Psychiatry and Behavioral Science, Texas A \& M Health Science Center College of Medicine, \\ Scott and White Hospital, Temple, TX, USA \\ Email: drdanielwilliams@gmail.com
}

Received 20 May 2014; revised 27 June 2014; accepted 15 July 2014

Copyright (C 2014 by authors and Scientific Research Publishing Inc. This work is licensed under the Creative Commons Attribution International License (CC BY). http://creativecommons.org/licenses/by/4.0/

(c) (i) Dpen Access

\begin{abstract}
Objective: To complete a systematic review of the literature addressing major depression in resident physicians. Methods: In 2013, the authors completed a systematic review of articles addressing major depression in physicians in United States residency programs. The following keywords were used: anxiety, stress, and mood, medical residents or interns, physician residents, graduate medical education, depression, stress or anxiety, and suicide. Results: The prevalence of depression in resident physicians is higher than that of the general population. Many sociodemographic and residency-associated factors have been studied in their relation to resident physician depression. Only physical health, an unhappy childhood, and stress at work were found to have association with depression, while the amount of call, lifestyle, age, income, and season of the year were not associated with depression. Other factors had an equivocal relationship. Depression in resident physicians is associated with medical errors, decreased ability to handle work-related stress, leaves of absence, discontinuation of medical training, disruption in personal lives, and suicide. Intervention with treatment for depression, using a low-cost, confidential, off-campus program, was successful. However, physicians may hesitate to seek treatment for mental illness because of the professional consequences, such as difficulty with medical licensing, hospital privileges, and malpractice insurance. Conclusions: Major depression is common in resident physicians in the United States. It has a negative impact on the lives of the doctors and the patients whom they treat. There appear to be effective ways of assisting residents with major depression available to training programs.
\end{abstract}

\section{Keywords}

Medical Residents, Major Depression, Systematic Review, Physician Health 


\section{Introduction}

"On the thirteenth day of his internship...Dr. K went to a fifth floor hospital lounge where he was observed...pacing for several minutes periodically touching the thicker inner pane of window glass separated from an outer pane by a venetian blind... A few minutes later, when alone in the lounge, he lunged toward the window and dove through both panes to his death 60 feet below."

-From Suicide and the Stress of Residency Training: A Case Report and Review of the Literature. Psychological Reports, 1989 (Kirsling et al., 1989).

Depression is a common, often untreated illness that has a devastating impact on interpersonal and workplace functioning. The National Comorbidity Survey replication study found a 16\% lifetime prevalence of major depressive disorder and $6.6 \%$ prevalence in the 12 months prior to the survey. Nearly $97 \%$ of those reporting major depression in the past year reported at least 35 days where they were unable to function due to depression (Kessler et al., 2003). Employees with depression have more sick days, less productivity, and are more likely to get terminated (Katon, 2009).

Many studies have shown that depression or emotional impairment in resident physicians is more common than that in the general population and result in patient care errors, leaves of absence, career changes, or suicide (Collier et al., 2002; Craig et al., 1968; Fahrenkopf et al., 2008; Reuben, 1985; Revicki et al., 1993; Smith et al., 1986; West et al., 2006; West et al., 2009). The potential public health implications of this are apparent considering the nature of resident physicians' work and the potential loss of future healthcare providers.

Our goal is to describe the current literature addressing major depression in resident physicians in a narrative fashion that will allow the reader to better understand its risk factors. This systematic review will address the incidence and prevalence of resident physician depression, sociodemographic and residency program factors associated with depression, the apparent consequences of depression in residents, the approaches to screening treatment that have been studied, and a discussion of possible barriers to the access and receipt of treatment.

\section{Methods}

PubMed, Psych-Info, Academic Search Premier, and CINAHL were searched for English language articles with any publication date addressing depression in resident physicians. A study was included if it was conducted in the United States, specifically addressed depression in resident physicians, discussed sociodemographic or residency program factors associated with depression, or addressed consequences of depression, including suicide.

The following MeSH terms were used to search PubMed: internship and residency, and depression, or suicide, with keywords anxiety, stress, and mood. The terms used in the remaining databases included: medical residents or interns, physician residents, graduate medical education, depression, stress or anxiety, and suicide. Studies were excluded because they addressed only resident "burnout," “fatigue,” "stress,” “anxiety,” or generalities such as "mood” or "emotional distress;" contained data related to physicians, but not specifically to resident physicians; were conducted outside of the United States; or were commentaries.

\section{Results}

The initial search of all databases yielded 120 articles, with 8 articles overlapping in the different searches, leaving 112 articles for review. After initial abstract review, 31 articles were excluded from the PubMed search, and 49 were excluded from the Psych-Info, Academic Search Premier, and CINAHL databases search. The abstracts of the reference articles of the final 32 articles were reviewed and those that addressed depression in resident physicians were also included in this review, adding 14 more articles for a total of 46 articles for this literature review.

\subsection{Prevalence of Depression in Resident Physicians}

Table 1 includes articles attempting to describe the prevalence of depression in resident physicians. Overall, prevalence from these studies ranged from 1\% to 56\% (Becker et al., 2006; Clark et al., 1984; Collier et al., 2002; Fahrenkopf et al., 2008; Ford et al., 1984; Godenick et al., 1995; Goebert et al., 2009; Goitein et al., 2005; Gopal et al., 2005; Hainer et al., 1998; Hendrie et al., 1990; Hillhouse et al., 2000; Katz et al., 2006; Kirsling et al., 1989; Pasnau et al., 1971; Pasnau et al., 1975; Reuben, 1985; Revicki et al., 1993; Rosen et al., 2006; Russell et al., 1975; Samuel et al., 1991; Schneider et al., 1993; Sen et al., 2010; Valko et al., 1975; Yi et al., 2006). The 
Table 1. Summary of studies addressing the prevalence of depression in resident physicians.

\begin{tabular}{|c|c|c|c|c|c|}
\hline Title & $\begin{array}{l}\text { Author/ } \\
\text { Year published }\end{array}$ & Population studied & $\mathrm{N}$ & $\begin{array}{c}\text { Depression } \\
\text { assessment tool }\end{array}$ & $\begin{array}{c}\text { Percent of subjects reporting } \\
\text { depression }\end{array}$ \\
\hline $\begin{array}{l}\text { A prospective } \\
\text { cohort study } \\
\text { investigating } \\
\text { factors associated } \\
\text { with depression } \\
\text { during internship }\end{array}$ & $\begin{array}{l}\text { Sen et al. } \\
\text { (2010) }\end{array}$ & $\begin{array}{l}\text { Internal medicine, } \\
\text { Family medicine, } \\
\text { General surgery, } \\
\text { Pediatrics, OB-Gyn, } \\
\text { and Psychiatry interns } \\
\text { at } 13 \text { US } \\
\text { hospitals }\end{array}$ & 740 & PHQ-9 & 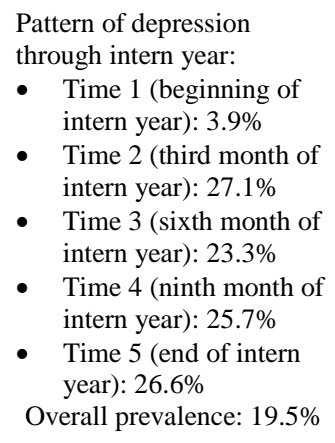 \\
\hline $\begin{array}{l}\text { Depressive symptoms } \\
\text { in medical students } \\
\text { and residents: a } \\
\text { multischool study }\end{array}$ & $\begin{array}{l}\text { Goebert et al. } \\
\text { (2009) }\end{array}$ & $\begin{array}{c}\text { Residents in } \\
\text { various fields at } \\
\text { six universities and } \\
\text { hospitals }\end{array}$ & 532 & CES-D & $11.9 \%$ \\
\hline $\begin{array}{l}\text { Rates of medication } \\
\text { errors among } \\
\text { depressed and burnt } \\
\text { out residents: } \\
\text { prospective } \\
\text { cohort study }\end{array}$ & $\begin{array}{c}\text { Fahrenkopf } \\
\text { et al. } \\
\text { (2008) }\end{array}$ & $\begin{array}{l}\text { Pediatric and } \\
\text { Medicine-Pediatric } \\
\text { residents at hospitals } \\
\text { in Boston, California, } \\
\text { and Washington D.C. }\end{array}$ & 123 & HANDS & $20 \%$ \\
\hline $\begin{array}{l}\text { Evolution of sleep } \\
\text { quantity, sleep } \\
\text { deprivation, mood } \\
\text { disturbances, } \\
\text { empathy and burnout } \\
\text { among interns }\end{array}$ & $\begin{array}{l}\text { Rosen et al. } \\
\text { (2006) }\end{array}$ & $\begin{array}{l}\text { Internal Medicine } \\
\text { interns at University } \\
\text { of Pennsylvania }\end{array}$ & $\begin{array}{l}58 \text { (time 1) } \\
47 \text { (time 2) }\end{array}$ & BDI-short form & $\begin{array}{l}\text { Pattern of depression } \\
\text { through intern year: } \\
\text { - Time } 1 \text { (beginning of } \\
\text { intern year): } 4.3 \% \\
\text { - Time } 2 \text { (end of intern } \\
\text { year): } 29.8 \%\end{array}$ \\
\hline $\begin{array}{l}\text { Burnout, depression, } \\
\text { and career satisfaction: } \\
\text { cross-sectional study } \\
\text { of obstetrics and } \\
\text { gynecology residents }\end{array}$ & $\begin{array}{l}\text { Becker et al. } \\
\text { (2006) }\end{array}$ & $\begin{array}{l}\text { OB-Gyn residents at } \\
23 \text { different programs } \\
\text { across the United States }\end{array}$ & 125 & CES-D & $34.2 \%$ \\
\hline $\begin{array}{l}\text { Religion, Spirituality, } \\
\text { and depressive } \\
\text { symptoms in primary } \\
\text { care house officers }\end{array}$ & $\begin{array}{l}\text { Yi et al. } \\
\text { (2006) }\end{array}$ & $\begin{array}{l}\text { Residents from } \\
\text { Pediatrics, Internal } \\
\text { Medicine-Pediatrics, } \\
\text { Internal Medicine, } \\
\text { Family Medicine at } \\
\text { University of Cincinnati }\end{array}$ & 227 & 10 item CES-D & $25 \%$ \\
\hline $\begin{array}{l}\text { Depression among } \\
\text { emergency medicine } \\
\text { residents over an } \\
\text { academic year }\end{array}$ & $\begin{array}{l}\text { Katz et al. } \\
\text { (2006) }\end{array}$ & $\begin{array}{l}\text { Emergency Medicine } \\
\text { residents at a large, } \\
\text { urban teaching hospital }\end{array}$ & 31 & CES-D & $12.1 \%$ \\
\hline $\begin{array}{l}\text { Burnout and Internal } \\
\text { Medicine resident } \\
\text { work-hour restrictions }\end{array}$ & $\begin{array}{l}\text { Gopal et al. } \\
\text { (2005) }\end{array}$ & $\begin{array}{l}\text { Internal Medicine } \\
\text { residents at University } \\
\text { of Colorado Health } \\
\text { Science Center }\end{array}$ & $\begin{array}{l}\text { Prior to work hour } \\
\text { restrictions: } 121 \text {, } \\
\text { After work hour } \\
\text { restrictions: } 106\end{array}$ & PRIME-MD & $\begin{array}{l}\text { Residents who screened } \\
\text { positive for depression } \\
\text { decreased from } 51 \% \text { to } 41 \% \\
\text { after hours were restricted }\end{array}$ \\
\hline $\begin{array}{l}\text { The effects of } \\
\text { work-hour limitations } \\
\text { on resident well-being, } \\
\text { patient care, and } \\
\text { education in an } \\
\text { internal medicine } \\
\text { residency program }\end{array}$ & $\begin{array}{l}\text { Goitein et al. } \\
\text { (2005) }\end{array}$ & $\begin{array}{l}\text { Internal Medicine } \\
\text { residents at the } \\
\text { University of } \\
\text { Washington }\end{array}$ & 118 & PRIME-MD & $\begin{array}{l}45 \% \text { screened positive for } \\
\text { depression before work hour } \\
\text { restrictions vs. } 56 \% \text { after } \\
\text { work hour restrictions }\end{array}$ \\
\hline
\end{tabular}




\section{Continued}

Stress in medical residency: status quo after a decade of reform?

\section{residents in programs \\ throughout the United States}

Residents were asked about five depressive symptoms (appetite changes, mood swings, decreased recreational activities, depressed mood, sleep disturbance)

Symptoms of a South Carolina family practice research consortium study

Physical and psychological health of family practice residents

Impact of work environment characteristics on work-related stress and depression in emergency medicine residents: a longitudinal study
Hainer et al. (1998)

Godenick et al. (1995) Revicki et al.
(1993)
Family Medicine residents at seven residency programs in South Carolina

Family Medicine residents in seven residency programs in South Carolina

\section{Emergency Medicine residents across the United States} residents, 369 2nd yr 92 3rd yr residents depression in residents:
Internal Medicine,

Depression and anxiety in medical, surgical, and pediatric interns

Investigating stress levels of residents: a pilot study

A study of anxiety/depressive symptoms of medical students, house staff, and their

spouses/partners

An evaluation of mood states among first-year residents

Depressive symptoms in medical house officers. Effects of work rotation

Aneasthesiology,

Pediatric, and

Samuel et al. (1991)

Psychiatry residents at a metropolitan university hospital

Housestaff

Hendrie et al. (1990)

department not specified) at a

Midwestern hospital

Interns in various

Kirsling et al.

(1989)

$$
\begin{array}{cc}
\text { Reuben } & \text { All residents at } \\
\text { (1985) } & \text { Brown University }
\end{array}
$$
level of training and

$\begin{array}{ccc}\text { Schneider et al. } & \text { Surgery, and Pediatric } & 33 \text { (time 2), } \\ \text { (1993) } & \text { interns at a community } & 32 \text { (time 3), } \\ \text { teaching hospital } & 32 \text { (time 4) }\end{array}$
specialties at Medical participated in

58 (4 of those personal interview)

SCL-90-R

BDI

Questionnaire asking residents to quantify how often they feel depressed, on a Likert scale-from most of the time, to never

BDI, personal interview

227 residents
$35 \%$ reported 4 of 5 symptoms of depression, $22 \%$ reported all 5 symptoms (n)

CES-D
$27 \%$ first-year residents $23 \%$ second-year residents $22 \%$ third-year residents

- Pattern of depression through intern year:

- Time 1 (beginning of intern year): $34.2 \%$

- Time 2 (fourth month of intern year): $42.4 \%$

- Time 3 (eighth month of intern year): $28.1 \%$

- $\quad$ Time 4 (end of intern year): $37.5 \%$

$16 \%$ with mild mood disturbance, $1 \%$ with moderate depression, $83 \%$ with normal mood scores.

$18 \%$ reported feeling depressed much or most of the time since beginning residency.

$15.5 \%$
Overall 21.4\% $28.7 \%$ first year residents $21.5 \%$ second year residents $10.3 \%$ third year residents 


\section{Continued}

\begin{tabular}{|c|c|c|c|c|c|}
\hline $\begin{array}{l}\text { The internship year: a } \\
\text { study of sleep, mood } \\
\text { states, and } \\
\text { psychophysiologic } \\
\text { parameters }\end{array}$ & $\begin{array}{l}\text { Ford et al. } \\
\quad(1984)\end{array}$ & $\begin{array}{c}\text { Interns of different } \\
\text { specialties at Vanderbilt }\end{array}$ & 27 & $\begin{array}{l}\text { POMS and personal } \\
\text { interview }\end{array}$ & $14.8 \%$ \\
\hline $\begin{array}{l}\text { Predictors of depression } \\
\text { during the first } 6 \\
\text { months of internship }\end{array}$ & $\begin{array}{l}\text { Clark et al. } \\
\text { (1984) }\end{array}$ & $\begin{array}{l}\text { Internal Medicine, } \\
\text { Surgery, OB-Gyn, } \\
\text { Pediatric interns at a } \\
\text { midwestern university }\end{array}$ & 55 & $\begin{array}{l}\text { BDI and personal } \\
\text { interview }\end{array}$ & $\begin{array}{c}\text { Pattern of depression } \\
\text { through internship: } \\
10 \% \text { at start of internship, } \\
7 \% 6 \text { months into intern year. } \\
27 \% \text { reported an episode of } \\
\text { major depression between the } \\
\text { beginning and end of intern } \\
\text { year. }\end{array}$ \\
\hline $\begin{array}{l}\text { Depression in the } \\
\text { Internship }\end{array}$ & $\begin{array}{l}\text { Valko et al. } \\
\text { (1975) }\end{array}$ & $\begin{array}{l}\text { Internal Medicine, } \\
\text { Surgery, Pediatrics, } \\
\text { Ophthalmology, } \\
\text { Dermatology, } \\
\text { Radiology, Neurology } \\
\text { interns at a Missouri } \\
\text { hospital }\end{array}$ & 53 & $\begin{array}{l}\text { Feighner criteria, } \\
\text { personal interview } \\
\text { by psychologist }\end{array}$ & $30 \%$ \\
\hline
\end{tabular}

BDI = Beck Depression Inventory; CES-D = Center for Epidemiologic Studies Depression Scale; HANDS = Harvard national depression screening day scale; PHQ-9 = Patient Health Questionnaire; POMS = Profile of Mood States; PRIME-MD = Primary Care Evaluation of Mental Disorders; SCL-90-R = Symptom Checklist-90-Revised.

largest study evaluated 4128 internal medicine residents, with $22 \%$ to $35 \%$ reporting between four to five symptoms of depression (Collier et al., 2002). One study evaluated 740 interns at US hospitals, $20 \%$ of whom reported depression (Sen et al., 2010). Among three cohorts of emergency medicine residents across the United States, 27\% of 556 first-year residents, 23\% of 369 second-year residents, and 22\% of 192 third-year residents screened positive for depression (Revicki et al., 1993). Depression was reported by $21 \%$ of 727 first, second, and third year residents at Brown University (Reuben, 1985). The remaining studies in Table 1 were based at only one institution or included a smaller number of participants.

\subsection{Incidence and Severity of Depression in Resident Physicians}

In a study involving 740 interns, $4 \%$ were depressed at the start of internship, $27 \%$ reported depression by the end of the first quarter, and $26 \%$ by the end of internship (Sen et al., 2010). In a study of 55 residents, $10 \%$ reported depression at the start of internship and 7\% six months into the internship year (Clark et al., 1984).

Nine studies examined the change in depression severity throughout intern year. Five of those studies found that the level of depression peaked anywhere between the third and eighth months of intern year, and lowered by the end of intern year; however, scores never lowered to baseline (Bellini et al., 2002; Bellini et al., 2005; Elliot et al., 1986; Girard et al., 1986; Sen et al., 2010). In one study, depression severity continued to rise throughout intern year, with no improvement at the end of the year. The remaining three studies did not find any change in severity of depression during the intern year (Ford et al., 1984; Gordon et al., 1986; Uliana et al., 1984). In a cohort of 43 residents followed throughout their residency, depression severity peaked during the intern year, improved significantly during the second and third years, but never decreased to baseline (Girard et al., 1991).

\subsection{Sociodemographic and Residency Program Factors Associated with Depression in Resident Physicians}

Table 2 summarizes factors studied in relation to depression. We have detailed findings below.

\subsubsection{Residency Program Factors}

Level of training. Some studies suggest that junior residents are more likely to be depressed, with the most depression occurring during internship year at $28 \%$, decreasing to $21 \%$ during second year, and to $10 \%$ during third year (Reuben, 1985; Revicki et al., 1993). Other studies reported no association between depression and level of training (Becker et al., 2006; Fahrenkopf et al., 2008; Goebert et al., 2009; Hainer et al., 1998; Hendrie et al., 1990). 
Table 2. Sociodemographic and residency program factors associated with depression in resident physicians.

\begin{tabular}{|c|c|}
\hline FACTOR & ASSOCIATION \\
\hline Physical health & $\mathrm{Y}$ \\
\hline Unhappy childhood & $\mathrm{Y}$ \\
\hline Stress at work ${ }^{*}$ & $\mathrm{Y}$ \\
\hline Amount of call & - \\
\hline Lifestyle $†$ & - \\
\hline Age & - \\
\hline Income & - \\
\hline Season of year & - \\
\hline Level of training & $\mathrm{Y} / \mathrm{N}$ \\
\hline Hours worked & $\mathrm{Y} / \mathrm{N}$ \\
\hline $\begin{array}{l}\text { Amount of sleep/sleep } \\
\text { deprivation }\end{array}$ & $\mathrm{Y} / \mathrm{N}$ \\
\hline Difficulty/type of rotation & $\mathrm{Y} / \mathrm{N}$ \\
\hline Previous history of depression & $\mathrm{Y} / \mathrm{N}$ \\
\hline Family history of mental illness & $\mathrm{Y} / \mathrm{N}$ \\
\hline Negative religious coping ${ }^{\ddagger}$ & $\mathrm{Y} / \mathrm{N}$ \\
\hline Stressors outside work & $\mathrm{Y} / \mathrm{N}$ \\
\hline Gender & $\mathrm{Y} / \mathrm{N}$ \\
\hline Ethnicity & $\mathrm{Y} / \mathrm{N}$ \\
\hline Marital status/social support & $\mathrm{Y} / \mathrm{N}$ \\
\hline Financial debt & $\mathrm{Y} / \mathrm{N}$ \\
\hline $\mathrm{Y}$ & All studies found this factor to be associated with depression \\
\hline $\mathrm{N}$ & No studies found this factor to be associated with depression \\
\hline $\mathrm{Y} / \mathrm{N}$ & $\begin{array}{l}\text { Some studies found an association with depression, some studies } \\
\text { failed to find an association with depression }\end{array}$ \\
\hline
\end{tabular}

${ }^{*}$ Hainer et al. 24 looked at perceived stress, Revicki et al. 10 used the work-related strain inventory to measure occupational stress; ${ }^{\dagger}$ Exercise and diet habits, alcohol intake; ${ }^{\ddagger}$ Negative religious coping is defined as spiritual discontent, reappraisals of God’s powers, spiritual abandonment, and poor spiritual well-being (not defined).

Amount of call. Studies have not shown a decrease in depressive symptoms following the ACGME duty hour restrictions on overnight call (Goebert et al., 2009; Sen et al., 2013; Valko et al., 1975).

Hours worked. To date, studies have not found a clear association between work hours and reports of depression (Goitein et al., 2005; Gopal et al., 2005; Stamp et al., 2005). In addition, four of the five studies addressing this did not find an association between depression and logged number of hours worked (Fahrenkopf et al., 2008; Katz et al., 2006; Kirsling et al., 1989; Sen et al., 2010; Valko et al., 1975).

Amount of sleep or sleep deprivation. In one study, residents with probable major depression slept 6.2 hours per night, and those without depression slept 6.64 hours per night (Goebert et al., 2009). Reporting less than six hours of sleep and becoming chronically sleep deprived was associated with depression (Godenick et al., 1995; Rosen et al., 2006). However, other studies did not find an association between depression scores and logged sleep hours (Fahrenkopf et al., 2008; Ford et al., 1984; Kirsling et al., 1989).

The difficulty or type of rotation. Residents reporting higher degrees of depression also ranked their current rotations as more difficult (Goebert et al., 2009). More depressive symptoms were reported on ICU, inpatient, and emergency room rotations (Reuben, 1985; Yi et al., 2006). One study did not find a relationship between depression and type of rotation (Valko et al., 1975).

\subsubsection{Residents' Medical and Social History}

Previous history of depression. Residents with a history of depression appear more likely to develop depression after starting residency (30.3\% versus 9.6\%) (Goebert et al., 2009; Katz et al., 2006). However, other studies report that a resident with a history of major depression did not evidence more depression than those without a history of depression (Clark et al., 1984; Kirsling et al., 1989). 
Physical health. Studies have shown that the odds of having depression were increased in resident physicians reporting poor physical health and fitness (Godenick et al., 1995; Hainer et al., 1998; Yi et al., 2006).

Family history of mental illness. Resident physicians with a family history of depression had a higher occurrence of depression compared to those without (Clark et al., 1984; Goebert et al., 2009; Valko et al., 1975). However, one study did not report an association (Kirsling et al., 1989).

Childhood. The odds of having depression were increased in those with an unhappy or difficult childhood (Godenick et al., 1995; Hainer et al., 1998; Sen et al., 2010).

Religiosity. There is a significant relationship between depression, negative religious coping (including spiritual discontent, reappraisals of God's powers, and spiritual abandonment) and poor spiritual well-being (Yi et al., 2006). However, in those with little or no religion, the prevalence of depression was not increased (Godenick et al., 1995).

Lifestyle. Exercise, diet habits, and amount of alcohol intake were not associated with depression (Becker et al., 2006; Hainer et al., 1998).

\subsubsection{Stress}

Stress at work. Work-related stress for resident physicians was associated with increased symptoms of depression (Hainer et al., 1998; Revicki et al., 1993; Revicki et al., 1993). In one study, work-related strain inventory scores were the strongest predictors of depression (Revicki et al., 1993). Residents whose tasks and roles at work were not clearly defined had a higher occurrence of depression (Revicki et al., 1993).

Stressors outside work. Several studies did not find an association between depression and recent stressful life events, such as death in the family or geographic relocation prior to starting residency (Clark et al., 1984; Godenick et al., 1995; Hainer et al., 1998; Kirsling et al., 1989). However, in one study, higher depressive symptoms correlated with stressful life events, highlighting the interplay between stress and mood (Sen et al., 2010).

\subsubsection{Demographic Factors}

Age. Resident age did not appear to be associated with depression (Becker et al., 2006; Fahrenkopf et al., 2008; Hainer et al., 1998; Revicki et al., 1993).

Gender. Several studies found that female residents were more likely to experience depression and with increased severity (Elliot et al., 1986; Goebert et al., 2009; Hendrie et al., 1990; Kirsling et al., 1989; Revicki et al., 1993; Sen et al., 2010). However, several other studies did not find a significant relationship between gender and depression (Becker et al., 2006; Clark et al., 1984; Fahrenkopf et al., 2008; Hainer et al., 1998; Katz et al., 2006; Koran et al., 1988; Revicki et al., 1993).

Ethnicity. Two studies analyzed ethnicity and resident physician depression and did not find a statistically significant relationship (Fahrenkopf et al., 2008; Goebert et al., 2009; Hainer et al., 1998). Another study showed higher depressive symptoms among European Americans (Fahrenkopf et al., 2008).

Marital status and social support. Several studies found that single residents or those who live alone had similar depression prevalence compared to those who were married (Becker et al., 2006; Clark et al., 1984; Fahrenkopf et al., 2008; Godenick et al., 1995; Hainer et al., 1998; Kirsling et al., 1989). However, other studies found that having low social support or being unmarried were associated with more symptoms of depression (Archer et al., 1991; Koran et al., 1988; Revicki et al., 1993).

Income. There was no reported association between depression and resident household income (Hainer et al., 1998).

Financial debt. Most studies did not find an association between depression and the level of indebtedness (Collier et al., 2002; Godenick et al., 1995; Hainer et al., 1998; Kirsling et al., 1989).

Season of year. In two studies, season of the year did not relate to resident physician depression (Hainer et al., 1998; Katz et al., 2006).

\subsection{Possible Consequences of Depression in Resident Physicians}

Between 2003 and 2006, residents at the Mayo Clinic self-reported their rate of perceived medical errors. Sixty-three percent of those who reported errors screened positive for depression (West et al., 2006). In another study, medication errors for depressed residents was 1.55 per month compared to 0.25 for non-depressed resi- 
dents (Fahrenkopf et al., 2008).

Depressed residents are more likely to find sleep deprivation, fatigue, working hours, and lack of time to provide good patient care as significantly more stressful than non-depressed residents (Kirsling et al., 1989). Residents who are depressed are more likely to continue working despite presence of any illness, have greater difficulty concentrating at work, and work in impaired conditions more than twice a month (Fahrenkopf et al., 2008). Among internal medicine residents across the United States between 1979 through 1984, 1\% required leaves of absence secondary to emotional impairment, $23 \%$ of which were diagnosed with depression. Of those impaired, $10 \%$ dropped out of medicine completely (Smith et al., 1986).

Depression in resident physicians also appears to lead to career dissatisfaction (Becker et al., 2006; Girard et al., 1986; Gordon et al., 1987; Hainer et al., 1998). Residents dissatisfied with their career choice in medicine were twice as likely to be depressed (Becker et al., 2006).

Depression in residents also appears to affect life outside of work. Marital problems were reported by $46 \%$ of the depressed interns versus 7\% of the non-depressed (Valko et al., 1975).

Suicide is a devastating consequence of depression in resident physicians. A study looking at emotional impairment in housestaff reported that 3\% of those "emotionally impaired" attempted suicide and an additional $2 \%$ completed suicide. In that study, "emotionally impaired" referred to depression as well as other psychiatric disorders; however, the majority of the emotionally impaired were diagnosed with depression (Smith et al., 1986). In 1973, the suicide rate for residents was 18 per 100,000 per year (Kelly, 1973). This rate is higher than the general population but hasn't been studied systematically since that time. Depressed residents are at an increased risk for suicide because they are prone to a failed sense of belonging, perceived burdensomeness, and an acquired ability to self-harm. A thwarted sense of belongingness stems from training environments that are not always conducive to obtaining adequate levels of social support. Residents may be prone to feeling emotionally burdensome as a result of depression. Finally, residents become habituated to the suffering associated with self-injury and death. Additionally, they are familiar with properties and lethal dosing of medications (Cornette et al., 2009).

\subsection{Treatment of Depression in Resident Physicians}

Fortunately, a growing number of programs targeting resident depression have been evaluated in recent years. At UCLA, the Mental Health Program for Physicians in Training offered an off-campus location that operated autonomously and provided confidential, affordable evaluation and treatment of psychiatric illnesses (Borenstein, 1985). Ninety-eight percent of residents $(n=89)$ who sought help did so voluntarily. Utilization was highest during the first and third years of residency. Depression was diagnosed in $62.9 \%$ of those who sought treatment. The treating psychiatrists reported that $96 \%$ of residents who received long-term treatment showed benefit (Borenstein, 1985). In another reported treatment model, a surgery residency employed a staff psychologist. The psychologist provided stress-management education and identified residents with performance issues. Therapeutic counseling was the primary intervention recommended. Of twelve impaired residents described in the report, two changed careers before completing residency, two required inpatient treatment for addiction, and the remainder completed residency in good standing (Veldenz et al., 2003). This may be interpreted as a good outcome.

Regarding treatment preference for depressed residents, one study described that eighty percent of residents would attend support groups if in psychological distress, and would talk with a spouse, family member, friend, or fellow intern, and exercise or engage in other recreational activity as coping methods. Residents did not describe being interested in talking with an attending physician, program director, or discussing concerns at a staff conference (Kirsling et al., 1989). In addition, 60\% felt coping skills or stress management seminars would be useful, and between $30 \%$ to $60 \%$ said they would use confidential psychotherapy (Samuel et al., 1991). Although up to $20 \%$ of residents felt the need for counseling, only $2 \%$ received it, which was due to insufficient time, concerns over confidentiality or finances, worries over the stigma attached, and not knowing where to get help (Koran et al., 1988).

\section{Discussion}

Despite the importance of this topic, both for the welfare of physicians and their patients, our knowledge about depression in resident physicians remains incomplete. It could be argued that what we found overestimates the 
prevalence of resident physician depression. For example, findings consisted of primarily observational studies with small sample sizes based on single institutions with depression defined by a variety of screening tools. The use of self-report screening tools would allow a critical reviewer to argue that a diagnosis of depression (even in larger samples) cannot be made, unless validated against structured interviews. Our review is limited by the biases inherent in survey research (e.g., response bias and recall bias). Uniform criteria for defining "depression" were not used in all studies. Despite these limitations, it is also reasonable to suggest that depression in resident physicians is underestimated. Residents have admitted to answering questions inaccurately and presenting themselves in a more positive light out of fear of lack of confidentiality and subsequent negative performance evaluations (Samuel et al., 1991).

Resident physician depression is a public health problem. If the prevalence of resident physician depression is approximated at 20\%, there are 107,851 residents in the United States, and 21,570 residents in training who may be suffering from depression (ACGME, 2009). We can hope that the only consequence of untreated depression in a resident physician is a lowered quality of life for him or her. However, evidence would suggest that work performance may be decreased appreciably. On medical wards and intensive care units, poor work is translated into possible human injury and death (Clark et al., 1984; Fahrenkopf et al., 2008; Valko et al., 1975; West et al., 2006).

Physicians commit suicide at a rate greater than the general population (Schernhammer et al., 2004). It is well known that depression is a major risk factor for suicide, and we have seen that resident physicians appear to suffer from depression and suicide more than the general population. Despite this, residents may not receive depression treatment for fear of negative performance evaluations and medical licensing problems (Center et al., 2003; Samuel et al., 1991). Those fears are not unfounded. Licensing boards are more likely to inquire about psychiatric disorders than physical conditions, and there is concern that practicing physicians with psychiatric disorders may encounter discrimination when trying to obtain a medical license, hospital privileges, health insurance, and malpractice insurance (Association, 1984; Center et al., 2003; Hansen et al., 1998).

If depressed residents are at risk of killing patients and/or themselves, why there is so little discussion in the literature about managing this problem? We described the details of at least one program that appeared effective at helping depressed residents. Is the problem that effective programs are not present for residents depressed in distress? Or, is it complex social and professional barriers that stand between a depressed resident and effective treatment? It is unacceptable to imagine a medical training system where a physician would view suicide as more palatable than the personal or professional consequences of acknowledging a common and treatable mood disorder.

While there is no clear evidence that risk factors for resident depression are different than the general population, the need for confidential screening and treatment programs is clear. A good place to start may be with providing better treatment options for substance use disorders because of their increased prevalence among resident physicians and the association with negative mental health outcomes. A better epidemiologic understanding of depression in residents will improve our evidence base and hopefully translate into even more exemplary models of care for training physicians. Our colleagues' and patients' health and well-being are at stake.

\section{References}

ACGME (2009). Celebrating Teamwork: 2007-2008 Annual Report Retrieved February 28, 2010. www.acgme.org/acgmeweb/Portals/0/PDFs/an_2007-08AnnRep.pdf

Archer, L. R., Keever, R. R., Gordon, R. A., \& Archer, R. P. (1991). The Relationship between Residents’ Characteristics, Their Stress Experiences, and Their Psychosocial Adjustment at One Medical School. Academic Medicine, 66, 301-303. http://dx.doi.org/10.1097/00001888-199105000-00018

Association, A. P. (1984). Position Statement on Confidentiality of Medical Records: Does the Physician Have a Right to Privacy Concerning His or Her Own Medical Records? American Journal of Psychiatry, 141, 331-332.

Becker, J. L., Milad, M. P., \& Klock, S. C. (2006). Burnout, Depression, and Career Satisfaction: Cross-Sectional Study of Obstetrics and Gynecology Residents. American Journal of Obstetrics and Gynecology, 195, 1444-1449. http://dx.doi.org/10.1016/j.ajog.2006.06.075

Bellini, L. M., Baime, M., \& Shea, J. A. (2002). Variation of Mood and Empathy during Internship. Journal of the American Medical Association, 287, 3143-3146. http://dx.doi.org/10.1001/jama.287.23.3143

Bellini, L. M., \& Shea, J. A. (2005). Mood Change and Empathy Decline Persist during Three Years of Internal Medicine Training. Academic Medicine, 80, 164-167. http://dx.doi.org/10.1097/00001888-200502000-00013 
Borenstein, D. B. (1985). Should Physician Training Centers Offer Formal Psychiatric Assistance to House Officers? A Report on the Major Findings of a Prototype Program. American Journal of Psychiatry, 142, 1053-1057.

Center, C., Davis, M., Detre, T., Ford, D. E., Hansbrough, W., Hendin, H., \& Silverman, M. M. (2003). Confronting Depression and Suicide in Physicians: A Consensus Statement. JAMA, 289, 3161-3166. http://dx.doi.org/10.1001/jama.289.23.3161

Clark, D. C., Salazar-Grueso, E., Grabler, P., \& Fawcett, J. (1984). Predictors of Depression during the First 6 Months of Internship. American Journal of Psychiatry, 141, 1095-1098.

Collier, V. U., McCue, J. D., Markus, A., \& Smith, L. (2002). Stress in Medical Residency: Status Quo after a Decade of Reform? Annals of Internal Medicine, 136, 384-390. http://dx.doi.org/10.7326/0003-4819-136-5-200203050-00011

Cornette, M. M., deRoon-Cassini, T. A., Fosco, G. M., Holloway, R. L., Clark, D. C., \& Joiner, T. E. (2009). Application of an Interpersonal-Psychological Model of Suicidal Behavior to Physicians and Medical Trainees. Archives of Suicide Research, 13, 1-14. http://dx.doi.org/10.1080/13811110802571801

Craig, A. G., \& Pitts, F. N. (1968). Suicide by Physicians. Diseases of the Nervous System, 29, 763-772.

Elliot, D. L., \& Girard, D. E. (1986). Gender and the Emotional Impact of Internship. Journal of the American Medical Women's Association, 41, 54-56.

Fahrenkopf, A. M., Sectish, T. C., Arger, L. K., Sharek, P. J., Lewin, D., Chiang, V. W., Landrigan, C. P. et al. (2008). Rates of Medication Errors among Depressed and Burnt out Residents: Prospective Cohort Study. British Medical Journal, 336, 488-491. http://dx.doi.org/10.1136/bmj.39469.763218.BE

Ford, C. V., \& Wentz, D. K. (1984). The Internship Year: A Study of Sleep, Mood States, and Psychophysiologic Parameters. Southern Medical Journal, 77, 1435-1442.

Girard, D. E., Elliot, D. L., Hickam, D. H., Sparr, L., Clarke, N. G., Warren, L., \& Koski, J. (1986). The Internship-A Prospective Investigation of Emotions and Attitudes. The Western Journal of Medicine, 144, 93-98.

Girard, D. E., Hickam, D. H., Gordon, G. H., \& Robison, R. (1991). A Prospective Study of Internal Medicine Residents’ Emotions and Attitudes throughout Their Training. Academic Medicine, 66, 111-114.

http://dx.doi.org/10.1097/00001888-199102000-00014

Godenick, M. T., Musham, C., Palesch ,Y., Hainer, B. L., \& Michels, P. J. (1995). Physical and Psychological Health of Family Practice Residents. Family Medicine, 27, 646-651.

Goebert, D., Thompson, D., Takeshita, J., Beach, C., Bryson, P., Ephgrave, K. et al. (2009). Depressive Symptoms in Medical Students and Residents: A Multischool Study. Academic Medicine, 84, 236-241. http://dx.doi.org/10.1097/ACM.0b013e31819391bb

Goitein, L., Shanafelt, T. D., Wipf, J. E., Slatore, C. G., \& Anthony, L. B. (2005). The Effects of Work-Hour Limitations on Resident Well-Being, Patient Care, and Education in an Internal Medicine Residency Program. Archives of Internal Medicine, 165, 2601-2606. http://dx.doi.org/10.1001/archinte.165.22.2601

Gopal, F., Glasheen, J. J., Miyoshi, T. J., \& Prochazka, A. V. (2005). Burnout and Internal Medicine Resident Work-Hour Restrictions. Archives of Internal Medicine, 165, 2595-2600. http://dx.doi.org/10.1001/archinte.165.22.2595

Gordon, G. H., Girard, D. E., \& Hickam, D. H. (1987). Comparison of Mood Changes and Satisfaction among First-Year Medical Residents in Three Programs. Journal of Medical Education, 62, 428-430.

Gordon, G. H., Hubbell, F. A., Wyle, F. A., \& Charter, R. A. (1986). Stress during Internship-A Prospective Study of Mood States. Journal of General Internal Medicine, 1, 228-231. http://dx.doi.org/10.1007/BF02596188

Hainer, B. L., \& Palesch, Y. (1998). Symptoms of Depression in Residents: A South Carolina Family Practice Research Consortium Study. Academic Medicine, 73, 1305-1310. http://dx.doi.org/10.1097/00001888-199812000-00023

Hansen, T. E., Goetz, R. R., Bloom, J. D., \& Fenn, D. S. (1998). Changes in Questions about Psychiatric Illness Asked on Medical Licensure Applications between 1993 and 1996. Psychiatric Services, 49, 202-206.

Hendrie, H. C., Clair, D. K., Brittain, H. M., \& Fadul, P. E. (1990). A Study of Anxiety/Depressive Symptoms of Medical Students, House Staff, and Their Spouses/Partners. The Journal of Nervous and Mental Disease, 178, 204-207. http://dx.doi.org/10.1097/00005053-199003000-00009

Hillhouse, J. J., Adler, C. M., \& Walters, D. N. (2000). A Simple Model of Stress, Burnout and Symptomatology in Medical Residents: A Longitudinal Study. Psychology, Health \& Medicine, 5, 63-73. http://dx.doi.org/10.1080/135485000106016

Katon, W. (2009). The Impact of Depression on Workplace Functioning and Disability Costs. American Journal of Managed Care, 15, S322-S327.

Katz, E. D., Sharp, L., \& Ferguson, E. (2006). Depression among Emergency Medicine Residents over an Academic Year. Academic Emergency Medicine, 13, 284-287.

Kelly, W. A. (1973). Suicide and Psychiatric Education. American Journal of Psychiatry, 130, 463-468. 
Kessler, R. C., Berglund, P., Demler, O., Jin, R., Koretz, D., Merikangas, K. R. et al. (2003). The Epidemiology of Major Depressive Disorder: Results from the National Comorbidity Survey Replication (NCS-R). Journal of the American Medical Association, 289, 3095-3105. http://dx.doi.org/10.1001/jama.289.23.3095

Kirsling, R. A., Kochar, M. S., \& Chan, C. (1989). An Evaluation of Mood States among First-Year Residents. Psychological Reports, 65, 355-366. http://dx.doi.org/10.2466/pr0.1989.64.3.951

Kirsling, R. A., \& Kochar, M. S. (1989). Suicide and the Stress of Residency Training: A Case Report and Review of the Literature. Psychological Reports, 64, 951-959. http://dx.doi.org/10.2466/pr0.1989.64.3.951

Koran, L. M., \& Litt, I. F. (1988). House Staff Well-Being. The Western Journal of Medicine, 148, 97-101.

Pasnau, R., \& Bayley, S. J. (1971). Personality Changes in the First Year of Psychiatric Residency Training. American Journal of Psychiatry, 128, 79-84.

Pasnau, R. O., \& Russell, A. T. (1975). Psychiatric Resident Suicide: An Analysis of Five Cases. American Journal of Psychiatry, 132, 402-406.

Reuben, D. B. (1985). Depressive Symptoms in Medical House Officers. Effects of Level of Training and Work Rotation. Archives of Internal Medicine, 145, 286-288. http://dx.doi.org/10.1001/archinte.1985.00360020114019

Revicki, D. A., Whitley, T. W., Gallery, M. E., \& Allison Jr., J. E. (1993). Impact of Work Environment Characteristics on Work-Related Stress and Depression in Emergency Medicine Residents: A Longitudinal Study. Journal of Community \& Applied Social Psychology, 3, 273-284. http://dx.doi.org/10.1002/casp.2450030405

Revicki, D. A., Whitley, T. W., \& Gallery, M. E. (1993). Organizational Characteristics, Perceived Work Stress, and Depression in Emergency Medicine Residents. Behavioral Medicine, 19, 74-81. http://dx.doi.org/10.1080/08964289.1993.9937568

Rosen, I. M., Gimotty, P. A., Shea, J. A., \& Bellini, L. M. (2006). Evolution of Sleep Quantity, Sleep Deprivation, Mood Disturbances, Empathy and Burnout among Interns. Academic Medicine, 81, 82-85. http://dx.doi.org/10.1097/00001888-200601000-00020

Russell, A. T., Pasnau, R. O., \& Taintor, Z. C. (1975). Emotional Problems of Residents in Psychiatry. American Journal of Psychiatry, 132, 263-267.

Samuel, S. E., Lawrence, J. S., Schwartz, H. J., Weiss, J. C., \& Seltzer, J. L. (1991). Investigating Stress Levels of Residents: A Pilot Study. Medical Teacher, 13, 89-92. http://dx.doi.org/10.3109/01421599109036762

Schernhammer, E. S., \& Colditz, G. A. (2004). Suicide Rates among Physicians: A Quantitative and Gender Assessment (Meta-Analysis). American Journal of Psychiatry, 161, 2295-2302. http://dx.doi.org/10.1176/appi.ajp.161.12.2295

Schneider, S. E., \& Phillips, W. M. (1993). Depression and Anxiety in Medical, Surgical, and Pediatric Interns. Psychological Reports, 72, 1145-1146. http://dx.doi.org/10.2466/pr0.1993.72.3c.1145

Sen, S., Kranzler, H. R., Krystal, J. H., Speller, H., Chan, G., Gelernter, J., \& Guille, C. (2010). A Prospective Cohort Study Investigating Factors Associated with Depression during Medical Internship. Archive of General Psychiatry, 67, 557-565. http://dx.doi.org/10.1001/archgenpsychiatry.2010.41

Sen, S., Kranzler, H. R., Didwania, A. K., Schwartz, A. C., Amarnath, S., Kolars, J. C. et al. (2013). Effects of the 2011 Duty Hour Reforms on Interns and Their Patients: A Prospective Longitudinal Cohort Study. JAMA Internal Medicine, 173, 657-662. http://dx.doi.org/10.1001/jamainternmed.2013.351

Smith, J. W., Denny, W. F., \& Witzke, D. B. (1986). Emotional Impairment in Internal Medicine House Staff. Results of a National Survey. Journal of the American Medical Association, 255, 1155-1158. http://dx.doi.org/10.1001/jama.1986.03370090077024

Smith, J. W., Denny, W. F., \& Witzke, D. B. (1986). Emotional Impairment in Internal Medicine House Staff. Results of a National Survey. JAMA, 255, 1155-1158. http://dx.doi.org/10.1001/jama.1986.03370090077024

Stamp, T., Termuhlen, P., Miller, S., Nolan, D., Hutzel, P., Gilchrist, J., \& Johnson, R. M. (2005). Before and after Resident Work Hour Limitations: An Objective Assessment of the Well-Being of Surgical Residents. Current Surgery, 62, $117-121$. http://dx.doi.org/10.1016/j.cursur.2004.09.013

Uliana, R. L., Hubbell, F. A., Wyle, F. A., \& Gordon, G. H. (1984). Mood Changes during the Internship. Journal of Medical Education, 59, 118-123.

Valko, R. J., \& Clayton, P. J. (1975). Depression in the Internship. Diseases of the Nervous System, 36, 26-29.

Veldenz, H. C., Scott, K. K., Dennis, J. W., Tepas 3rd, J. J., \& Schinco, M. S. (2003). Impaired Residents: Identification and Intervention. Current Surgery, 60, 214-217. http://dx.doi.org/10.1016/S0149-7944(02)00780-8

West, C. P., Huschka, M. M., Novotny, P. J., Sloan, J. A., Kolars, J. C., Habermann, T. M., \& Shanafelt, T. D. (2006). Association of Perceived Medical Errors with Resident Distress and Empathy: A Prospective Longitudinal Study Journal of the American Medical Association, 296, 1071-1078. http://dx.doi.org/10.1001/jama.296.9.1071 
West, C. P., Tan, A. D., Habermann, T. M., Sloan, J. A., \& Shanafelt, T. D. (2009). Association of Resident Fatigue and Distress with Perceived Medical Errors. Journal of the American Medical Association, 302, 1294-1300. http://dx.doi.org/10.1001/jama.2009.1389

Yi, M. S., Luckhaupt, S. E., Mrus, J. M., Mueller, C. V., Peterman, A. H., Puchalaski, C. M., \& Tsevat, J. (2006). Religion, Spirituality, and Depressive Symptoms in Primary Care House Officers. Ambulatory Pediatrics, 6, 84-90. http://dx.doi.org/10.1016/j.ambp.2005.10.002 
Scientific Research Publishing (SCIRP) is one of the largest Open Access journal publishers. It is currently publishing more than 200 open access, online, peer-reviewed journals covering a wide range of academic disciplines. SCIRP serves the worldwide academic communities and contributes to the progress and application of science with its publication.

Other selected journals from SCIRP are listed as below. Submit your manuscript to us via either submit@scirp.org or Online Submission Portal.
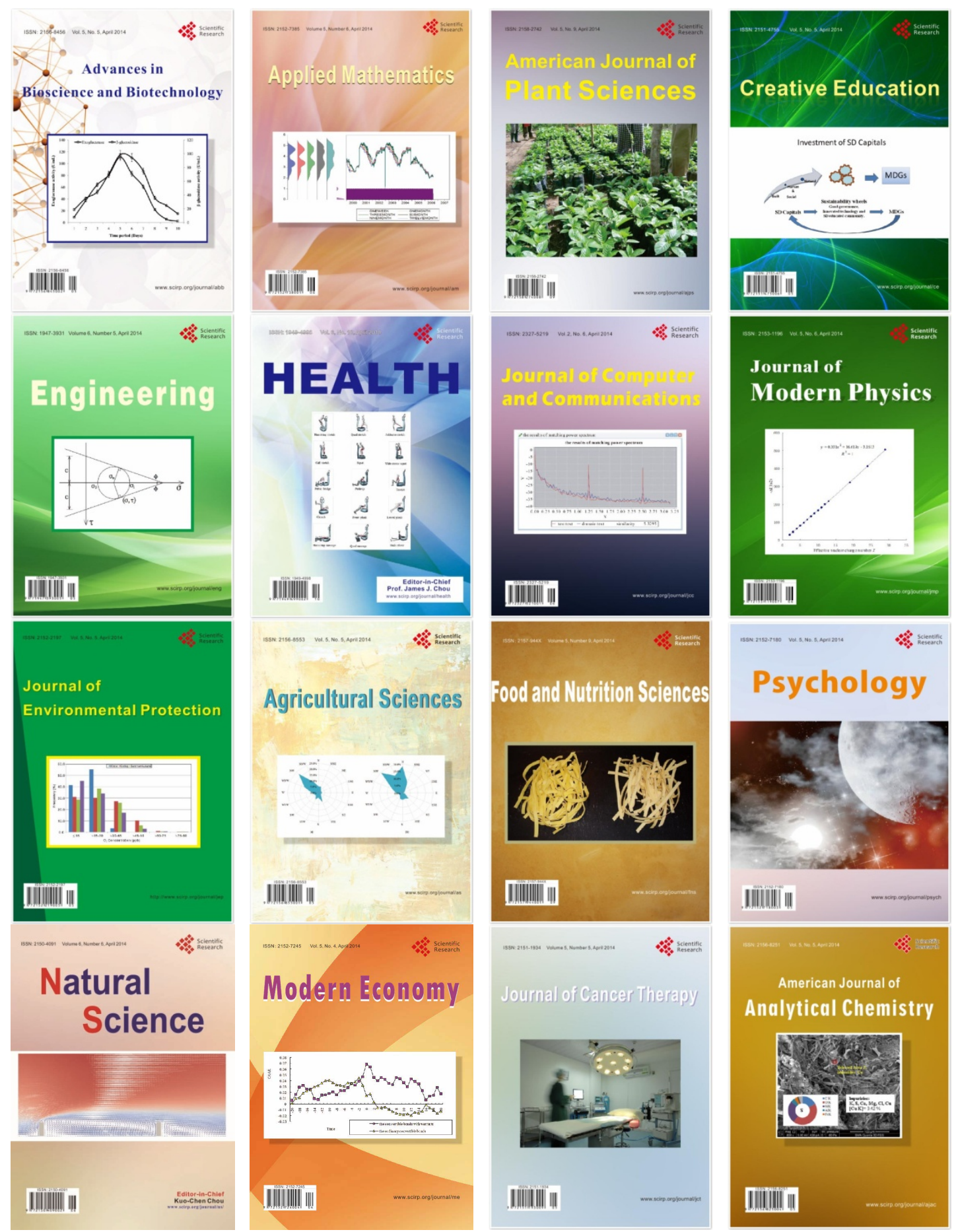